\title{
Projecting the impact of a two-dose COVID-19 vaccination campaign in Ontario, Canada
}

\author{
Thomas N. Vilches, ${ }^{1}$ Kevin Zhang, ${ }^{2, \dagger}$ Robert Van Exan, ${ }^{3}$ Joanne M. Langley, ${ }^{4}$ \\ Seyed M. Moghadas ${ }^{5}$ \\ ${ }^{1}$ Institute of Mathematics, Statistics and Scientific Computing, University of Campinas, \\ Campinas SP, Brazil \\ ${ }^{2}$ Faculty of Medicine, University of Toronto, Toronto, Ontario, M5S 1A8 Canada \\ ${ }^{3}$ Immunization Policy \& Knowledge Translation, Trent Lakes, Ontario, K0M 1A0, Canada \\ ${ }^{4}$ Canadian Center for Vaccinology, Dalhousie University, IWK Health Centre and Nova Scotia \\ Health Authority, Halifax, Nova Scotia, B3K 6R8 Canada \\ ${ }^{5}$ Agent-Based Modelling Laboratory, York University, Toronto, Ontario, M3J 1P3 Canada \\ †Corresponding author: kevink.zhang@mail.utoronto.ca
}

\begin{abstract}
Background: A number of highly effective COVID-19 vaccines have been developed and approved for mass vaccination. We evaluated the impact of vaccination on COVID-19 outbreak and disease outcomes in Ontario, Canada.

Methods: We used an agent-based transmission model and parameterized it with COVID-19 characteristics, demographics of Ontario, and age-specific clinical outcomes. We implemented a two-dose vaccination program according to tested schedules in clinical trials for PfizerBioNTech and Moderna vaccines, prioritizing healthcare workers, individuals with comorbidities, and those aged 65 and older. Daily vaccination rate was parameterized based on vaccine administration data. Using estimates of vaccine efficacy, we projected the impact of vaccination on the overall attack rate, hospitalizations, and deaths. We further investigated the effect of increased daily contacts at different stages during vaccination campaigns on outbreak control.
\end{abstract}

Results: Maintaining non-pharmaceutical interventions (NPIs) with an average of $74 \%$ reduction in daily contacts, vaccination with Pfizer-BioNTech and Moderna vaccines was projected to reduce hospitalizations by $27.3 \%$ (95\% Crl: $22.3 \%-32.4 \%)$ and $27.0 \%$ (95\% Crl: $21.9 \%-$ $32.6 \%$ ), respectively, over a one-year time horizon. The largest benefits of vaccination were observed in preventing deaths with reductions of $31.5 \%$ (95\% Crl: $22.5 \%-39.7 \%)$ and $31.9 \%$ (95\% Crl: $22.0 \%$ - 41.4\%) for Pfizer-BioNTech and Moderna vaccines, respectively, compared to no vaccination. We found that an increase of only $10 \%$ in daily contacts at the end of lockdown, when vaccination coverage with only one dose was $6 \%$, would trigger a surge in the outbreak. Early relaxation of population-wide measures could lead to a substantial increase in the number of infections, potentially reaching levels observed during the peak of the second wave in Ontario. 
medRxiv preprint doi: https://doi.org/10.1101/2020.12.10.20246827; this version posted March 18, 2021. The copyright holder for this preprint (which was not certified by peer review) is the author/funder, who has granted medRxiv a license to display the preprint in perpetuity. It is made available under a CC-BY-NC-ND 4.0 International license .

Conclusions: Vaccination can substantially mitigate ongoing COVID-19 outbreaks. Sustaining population-wide NPIs, to allow for a sufficient increase in population-level immunity through vaccination, is essential to prevent future outbreaks.

Keywords: COVID-19; vaccination; outbreak simulation

\section{Introduction}

Despite unprecedented public health measures, such as stay-at-home orders, school closures, and physical distancing (1-4), the novel coronavirus disease 2019 (COVID-19) has caused severe global health and tremendous economic consequences $(5,6)$. In Canada, these measures have been comparatively effective in flattening initial outbreaks $(7,8)$. However, despite continued non-pharmaceutical interventions (NPIs), the second wave proved to be a deadly outbreak, underscoring the importance of a safe and effective vaccine to control the ongoing pandemic.

With an accelerated pace of vaccine development, several vaccines have received approval after demonstrating relatively high efficacy in clinical trials (9). In Canada, Pfizer-BioNTech and Moderna vaccines were authorized for distribution in December 2020 (10). However, shortages in early vaccine supply hindered efforts to suppress the second wave, triggering lockdown in Canadian provinces. With improving rates of vaccination and increasing supply due to additional authorization of vaccines (i.e., Oxford-AstraZeneca and Janssen), there is a need to understand the potential impact of vaccination campaigns with vaccine prioritization (11), and timelines for lifting restrictive NPIs.

We sought to evaluate the impact of a COVID-19 vaccination campaign, based on a scenario with two doses of Pfizer-BioNTech or Moderna vaccines distributed, 21 or 28 days apart, on the overall attack rate, hospitalizations, and deaths in Ontario, the most populated Canadian province. We extended an agent-based model of disease transmission (12) to include vaccination with an age-specific uptake distribution prioritized based on recommendations outlined by the National Advisory Committee on Immunization $(13,14)$. We evaluated a roll-out strategy that prioritizes high risk adults (i.e., healthcare workers, elderly, and comorbid individuals), followed by the general population, to reduce transmission and severe outcomes $(11,13)$.

\section{Methods}

\section{Model structure}

We extended a previously established agent-based COVID-19 transmission model (12) and included vaccination to simulate outbreak scenarios. The natural history of COVID-19 was implemented in the model by considering individual status as susceptible; latently infected (not yet infectious); asymptomatic (infected and infectious but with no symptoms); pre-symptomatic (infected, infectious and in the stage before symptomatic illness); symptomatic with either mild 
medRxiv preprint doi: https://doi.org/10.1101/2020.12.10.20246827; this version posted March 18, 2021. The copyright holder for this preprint (which was not certified by peer review) is the author/funder, who has granted medRxiv a license to display the preprint in perpetuity. It is made available under a CC-BY-NC-ND 4.0 International license .

or severe/critical illness; recovered (and not infectious); and dead (Appendix, Figure A1). We binned the model population into six age groups of 0-4, 5-19, 20-49, 50-64, and 65-79, and 80+ years old based on the demographics of Ontario, Canada (15) and parameterized the model with estimates of the proportion of the population with comorbidities associated with severe COVID-19 (Appendix, Table A1) to allow for the implementation of vaccine prioritizations $(16,17)$. We assumed the same degree of susceptibility to infection across all age groups. Interactions between individuals were informed using an empirically determined contact network (18). The daily number of contacts for each individual was sampled from a negative-binomial distribution with age-dependent mean and standard deviation (Appendix, Table A2). The daily number of contacts during lockdown or self-isolation was reduced by an average of $74 \%$, based on a matrix derived from a representative sample population during COVID-19 lockdown (19).

\section{Disease dynamics}

We implemented disease transmission in a probabilistic manner whereby susceptible individuals were exposed to infectious individuals (i.e., asymptomatic, pre-symptomatic, or symptomatic stages of the disease). Infected individuals entered a latent period as part of an average incubation period of 5.2 days (20). For those who went on to develop symptomatic disease, the incubation period included a pre-symptomatic stage prior to the onset of symptoms (21), with a mean duration of 2.3 days sampled from a Gamma distribution with a mean (21). The infectious period post-symptom onset was also sampled from a Gamma distribution with a mean of 3.2 days (22). We considered an age-dependent probability of developing mild, severe, or critical illness after symptom onset. Infected individuals who did not develop symptoms remained asymptomatic after the latent period until recovery. Asymptomatic individuals were infectious for an average of 5 days, which was sampled from a Gamma distribution $(22,23)$.

Based on the number of secondary cases generated during each stage of the disease (24), we parameterized the infectivity of asymptomatic, mild symptomatic, and severe symptomatic stages to be $26 \%, 44 \%$, and $89 \%$ relative to the pre-symptomatic stage (24-26). We assumed that recovered individuals could not be re-infected during the same outbreak scenario.

\section{Infection outcomes}

In our model, mild symptomatic cases recovered without the need for hospitalization. A proportion of individuals with severe illness used hospital beds in this model. We parameterized the model for the use of intensive care unit (ICU) and non-ICU beds based on recent COVID-19 hospitalization data stratified by the presence of comorbidities in Ontario (17). We assumed that all symptomatic cases who were not hospitalized self-isolated within 24 hours of symptom onset for the entire symptomatic period. The time from symptom onset to hospital admission was uniformly sampled in the range of 2 to 5 days $(12,27)$. The lengths of non-ICU and ICU stays were sampled from Gamma distributions with means of 12.4 and 14.4 days, respectively $(28,29)$.

\section{Vaccination}

We implemented a two-dose vaccination campaign, with a daily vaccination rate that increased over time and saturated at 50 doses per day per 10,000 population (Appendix, Figure A2). 
medRxiv preprint doi: https://doi.org/10.1101/2020.12.10.20246827; this version posted March 18, 2021. The copyright holder for this preprint (which was not certified by peer review) is the author/funder, who has granted medRxiv a license to display the preprint in perpetuity. It is made available under a CC-BY-NC-ND 4.0 International license .

Vaccination was sequential with prioritization of: (i) healthcare workers, individuals with comorbidities, and those aged 65 and older (i.e., protection cohort); followed by (ii) individuals aged 16-64 (i.e., disruption minimization cohort) $(11,13)$. Children under 16 years of age were not vaccinated. In our model, the age-eligibility was 16+ for Pfizer-BioNTech vaccines, but 18+ for Moderna. We assumed that the maximum achievable coverage within a one-year time horizon was $95 \%$ among healthcare workers and those aged 65 and older. The maximum coverage was set to $70 \%$ among other age groups (Appendix, Table A3). Pre-existing immunity as a result of a primary infection with COVID-19 was not a factor in the vaccination of individuals.

For Pfizer-BioNTech vaccines, we assumed vaccination campaigns followed the recommended dosing interval (i.e., tested in clinical trials) of 21 days (30). This interval was 28 days for Moderna vaccines (31). Vaccine coverage of the entire population with two doses reached $62 \%$ for both Moderna and Pfizer-BioNTech within one year of the vaccination campaign.

We reviewed published studies and briefing documents for vaccine approvals on the efficacy of both Pfizer-BioNTech and Moderna vaccines in preventing infection, symptomatic disease, and severe disease (30-35). We implemented the estimated efficacies and associated timelines following the first dose of vaccine for each vaccinated individual (Appendix, Table A4).

\section{Model scenarios and implementation}

We considered a $5 \%$ level of pre-existing immunity accrued prior to the start of simulations (corresponding to October 1,2020 ) based on seroprevalence studies $(8,36)$. To distribute this level of population immunity, we first simulated the model in the absence of vaccination and derived the infection rates in different age groups when the overall attack rate reached $5 \%$ of the population. We then used the age-specific attack rates to initialize the proportion of the population with immunity in different age groups for the vaccination model.

We calibrated the transmission probability per contact to the effective reproduction number $R_{e}=1.12$ estimated in early October 2020, accounting for the effect of NPIs in Ontario (37). With this calibration and using parameters provided in Table 1 and Table A5 (Appendix), we fitted the model to the reported cases per 10,000 population over time from October 1, 2020 to March 8, 2021. Vaccination started on day 74 of the simulations (i.e., December 14, 2020). We averaged the results for the overall attack rate, hospitalizations, and deaths over 1000 independent Monte-Carlo realizations, and derived the credible intervals (at the $5 \%$ significance level) for reduction of attack rate and severe outcomes attributable to vaccination using a bias-corrected and accelerated bootstrap method (with 500 replications). The model was coded in Julia language and is available at: https://github.com/thomasvilches/vac covid ontario.

\section{Results}

From the start of vaccination on day 74 of simulations, we projected an overall attack rate of $1.7 \%(95 \% \mathrm{Crl}: 1.6 \%-1.9 \%)$ using Pfizer-BioNTech or Moderna vaccines, if the daily number of contacts did not change after the lockdown (stay-at-home order) period ended on day 158 (March 8, 2021) (Figure 1A). Maintaining NPIs in place, the reduction of attack rate attributable 
medRxiv preprint doi: https://doi.org/10.1101/2020.12.10.20246827; this version posted March 18, 2021. The copyright holder for this preprint (which was not certified by peer review) is the author/funder, who has granted medRxiv a license to display the preprint in perpetuity. It is made available under a CC-BY-NC-ND 4.0 International license .

to vaccination was projected to be $26.4 \%$ (95\% Crl: $22.0 \%-30.7 \%)$ for Pfizer-BioNTech and $27.5 \%$ (95\% Crl: $22.6 \%$ - 31.6\%) for Moderna vaccines over a one-year time horizon (Figure 1B). The corresponding reductions of hospitalizations were $27.3 \%$ (95\% Crl: $22.3 \%-32.4 \%)$ and $27.0 \%$ (95\% Crl: $21.9 \%-32.6 \%)$. The largest benefits of vaccination were observed in preventing deaths with reductions of $31.5 \%(95 \% \mathrm{Crl}: 22.5 \%-39.7 \%)$ and $31.9 \%(95 \% \mathrm{Crl}$ : $22.0 \%-41.4 \%)$ for Pfizer-BioNTech and Moderna vaccines, respectively, compared to no vaccination (Figure 1B).

If vaccines were not available, we projected an average of 49.9 (95\% Crl: 44.3 - 55.6) hospital bed-days per 10,000 population from day 74 onwards (Figure 1C). With vaccination, hospital bed-days reduced significantly to 36.7 (95\% Crl: 32.6 - 40.9) and 36.7 (95\% Crl: 32.8 - 40.6) per 10,000 population for Pfizer-BioNTech and Moderna vaccines, respectively.

\section{Insert Figure 1 Here}

\section{Effect of vaccination with increased daily contacts}

We simulated the effect of vaccination with increased daily number of contacts following the lockdown period, accounting for possible reduction in the adherence to NPIs. At the end of lockdown (day 158 of simulations), vaccination coverage with only one dose was $6 \%$ for both Pfizer-BioNTech and Moderna vaccines. At the same time, vaccination coverage of those who had received both doses was $1.7 \%$ and $1.9 \%$ for Pfizer-BioNTech and Moderna vaccines, respectively. If the daily number of contacts was increased by $10 \%$ immediately after lockdown ended (March 8, 2021), we observed a gradual increase in the case incidence, reaching a peak of 0.93 cases (on average) per 10,000 population within 40 days (Figure 2A). Increasing the daily number of contacts by $20 \%$ would lead to a significant increase in the daily incidence of infection, reaching a peak of 1.82 (on average) per 10,000 population within 60 days similar to the increasing incidence trend observed in late December 2020 during the second wave, which triggered the instigation of province-wide lockdown (Figure 2D).

If contacts post-lockdown did not change until day 200 (April 19, 2021), then a 10\% increase in daily number of contacts had no significant impact on the declining trend of the outbreak (Figure $2 \mathrm{~B}$ ). On day 200 , vaccination coverage with only one dose was $23 \%$, with coverage of $8.4 \%$ and $8.0 \%$ for both doses of Pfizer-BioNTech and Moderna vaccines, respectively. However, these vaccine coverages are still insufficient to prevent a surge in infections associated with larger increases in the daily number of contacts. For example, a $20 \%$ increase in contacts would lead to an increasing trajectory of the outbreak (Figure $2 \mathrm{E}$ ), approaching a peak with an incidence similar to that reported at the end of the lockdown period.

If contacts did not change until day 250 (June 10, 2021), there was no surge in the number of cases with a $10 \%$ or $20 \%$ increase in daily number of contacts (Figure $2 \mathrm{C}, 2 \mathrm{~F}$ ); although the outbreak would last longer, compared to the scenario in which there was no change in contacts post-lockdown (Figure 1A). On day 250 (day 176 after the start of the vaccination campaign), vaccination coverage with only one dose was $48 \%$, with coverage of $21 \%$ and $20 \%$ for both doses of Pfizer-BioNTech and Moderna vaccines, respectively. These results highlight the 
medRxiv preprint doi: https://doi.org/10.1101/2020.12.10.20246827; this version posted March 18, 2021. The copyright holder for this preprint (which was not certified by peer review) is the author/funder, who has granted medRxiv a license to display the preprint in perpetuity.

It is made available under a CC-BY-NC-ND 4.0 International license .

importance of maintaining NPIs to allow for a sufficient increase in population-level immunity through vaccination prior to lifting public health measures.

\section{Insert Figure 2 Here}

\section{Discussion}

Our results indicate that vaccination could have a large impact on reducing hospitalizations and deaths in Ontario, Canada. However, achieving this impact is contingent upon continued population-wide NPIs during the immunization program until there is adequate vaccination coverage. We found that without sufficient population immunity, even a $10 \%$ increase in daily contacts would reverse the declining trend of the outbreak achieved during the lockdown. Our results further highlight the importance of an accelerated vaccination rollout to prevent an outbreak surge that may arise due to the erosion of adherence to NPIs.

With the current and expected increases in daily vaccination rates, our results show that lifting restrictive measures before June 2021 is likely to trigger a resurgence of infections. This timeline is particularly important when considering the presence of new SARS-CoV-2 variants that have shown significantly higher transmissibility and risk of deaths compared to the original pandemic strain (41-44). Analysis of samples from Greater Toronto Area, the largest metropolitan population in Ontario, show an increase of over 6-fold in the spread of variants of concern from mid-December 2020 to early February 2021 (45). The transmissibility of these variants relative to the original strain was estimated to exceed 1.4 (45). Although our model does not explicitly include these variants, increasing daily contact rates could be considered as a proxy for a higher virus transmissibility. With over $30 \%$ positivity rate for variants of concern as of March 13, 2021 in Ontario (46), early relaxation of restrictive measures could lead to uncontrollable outbreaks as a result of reduced social distancing and wider spread of these variants.

Our results should be interpreted within the context of study assumptions and limitations. First, we assumed that vaccines would continue to be distributed according to the tested schedules in clinical trials. Recent evidence concerning vaccine efficacy after a single dose and with a delayed second dose (47-49) have led to changes in recommendations by Canada's National Advisory Committee on Immunization, extending dose intervals for COVID-19 vaccines to optimize early vaccine rollout. A delay in administering the second dose of vaccines would affect the overall level of population immunity and, therefore, warrants further investigation on the effect of timing and the degree to which NPIs are lifted on outbreak control. Second, we did not consider drop-out over the course of the vaccination program, which would affect the level of protection conferred by vaccination. Third, the daily rate of vaccination was parameterized based on administered doses thus far and the expected increase in vaccine distribution in the coming months. Fourth, the inclusion of Oxford-AstraZeneca and Janssen vaccines in rollout could affect our results due to differences in vaccine efficacies, number of doses, and uptake of these vaccines. Despite the proven safety and efficacy of current vaccines, vaccine hesitancy (50) may result in a slower increase in the vaccination coverage than assumed in our model. 
medRxiv preprint doi: https://doi.org/10.1101/2020.12.10.20246827; this version posted March 18, 2021. The copyright holder for this preprint (which was not certified by peer review) is the author/funder, who has granted medRxiv a license to display the preprint in perpetuity. It is made available under a CC-BY-NC-ND 4.0 International license .

Therefore, a highly efficient national adverse event reporting system will be critical to supporting public confidence and improving vaccine uptake.

Notwithstanding these considerations, our study indicates that, while vaccination with highly effective vaccines could significantly mitigate COVID-19 outbreaks, it is unlikely to eliminate the need for NPIs before a sufficiently high level of population immunity is achieved. Our results show that vaccination is a key public health measure in the fight against the COVID-19 pandemic.

Competing Interest. JML's institution has received funding for research studies from Sanofi Pasteur, GlaxoSmithKline, Merck, Janssen, Medicago, VBI, VIDO, Entos and Pfizer. JML holds the CIHR-GSK Chair in Paediatric Vaccinology. Other authors declare no competing interests.

Funding. SMM gratefully acknowledges the Canadian Institutes of Health Research OV4 170643, COVID-19 Rapid Research; and Natural Sciences and Engineering Research Council of Canada. TNV acknowledges the support of the São Paulo Research Foundation, grant \#2018/24811-1.

\section{References}

1. Lau H, Khosrawipour V, Kocbach P, Mikolajczyk A, Schubert J, Bania J, et al. The positive impact of lockdown in Wuhan on containing the COVID-19 outbreak in China. J Travel Med [Internet]. 2020 May 18 [cited 2020 Aug 24];27(3). Available from:

https://academic.oup.com/jtm/article/27/3/taaa037/5808003

2. Flaxman S, Mishra S, Gandy A, Unwin HJT, Mellan TA, Coupland H, et al. Estimating the effects of non-pharmaceutical interventions on COVID-19 in Europe. Nature [Internet]. 2020 Aug [cited 2020 Aug 24];584(7820):257-61. Available from: https://www.nature.com/articles/s41586-020-2405-7

3. Khosrawipour V, Lau H, Khosrawipour T, Kocbach P, Ichii H, Bania J, et al. Failure in initial stage containment of global COVID-19 epicenters. J Med Virol [Internet]. 2020 [cited 2020 Aug 24];92(7):863-7. Available from: https://onlinelibrary.wiley.com/doi/abs/10.1002/jmv.25883

4. The Lancet. India under COVID-19 lockdown. Lancet Lond Engl [Internet]. 2020 [cited 2020 Aug 24];395(10233):1315. Available from: https://www.ncbi.nlm.nih.gov/pmc/articles/PMC7180023/

5. COVID-19 Map [Internet]. Johns Hopkins Coronavirus Resource Center. [cited 2020 Aug 5]. Available from: https://coronavirus.jhu.edu/map.html

6. Fernandes N. Economic Effects of Coronavirus Outbreak (COVID-19) on the World Economy [Internet]. Rochester, NY: Social Science Research Network; 2020 Mar [cited 2020 Jul 9]. Report No.: ID 3557504. Available from: https://papers.ssrn.com/abstract=3557504

7. Public Health Agency of Canada. Coronavirus disease (COVID-19): Outbreak update [Internet]. 2020 [cited 2021 Mar 14]. Available from: https://www.canada.ca/en/publichealth/services/diseases/2019-novel-coronavirus-infection.html

8. COVID-19 Immunity Task Force. New study offers first glimpse into how widespread 
medRxiv preprint doi: https://doi.org/10.1101/2020.12.10.20246827; this version posted March 18, 2021. The copyright holder for this preprint (which was not certified by peer review) is the author/funder, who has granted medRxiv a license to display the preprint in perpetuity.

It is made available under a CC-BY-NC-ND 4.0 International license .

COVID-19 antibodies are in Canada's adult population [Internet]. COVID-19 Immunity Task Force. 2020 [cited 2020 Aug 18]. Available from:

https://www.covid19immunitytaskforce.ca/new-study-offers-first-glimpse-into-how-

widespread-covid-19-antibodies-are-in-canadas-adult-population/

9. Corum J, Wee S-L, Zimmer C. Coronavirus Vaccine Tracker [Internet]. The New York Times. [cited 2021 Mar 14]. Available from:

https://www.nytimes.com/interactive/2020/science/coronavirus-vaccine-tracker.html

10. Health Canada. Health Canada authorizes first COVID-19 vaccine [Internet]. 2020 [cited

2021 Mar 14]. Available from: https://www.canada.ca/en/health-

canada/news/2020/12/health-canada-authorizes-first-covid-19-vaccine0.html

11. World Health Organization. WHO Strategic Advisory Group of Experts (SAGE) on Immunization Working Group on COVID-19 Vaccines: Prioritized Infectious Disease and Economic Modelling Questions [Internet]. 2020 [cited 2020 Aug 19]. Available from: https://static1.squarespace.com/static/556deb8ee4b08a534b8360e7/t/5f2b412e6c92b204d f833836/1596670255207/SAGE+WG+COVID-

19+Vaccines_Modelling_Questions_31July2020.pdf

12. Shoukat A, Wells CR, Langley JM, Singer BH, Galvani AP, Moghadas SM. Projecting demand for critical care beds during COVID-19 outbreaks in Canada. Can Med Assoc J [Internet]. 2020 May 11 [cited 2020 Jun 10];192(19):E489-96. Available from:

http://www.cmaj.ca/lookup/doi/10.1503/cmaj.200457

13. Public Health Agency of Canada. Guidance on the prioritization of initial doses of COVID19 vaccine(s) [Internet]. 2020 [cited 2021 Mar 14]. Available from:

https://www.canada.ca/en/public-health/services/immunization/national-advisorycommittee-on-immunization-naci/guidance-prioritization-initial-doses-covid-19vaccines.html

14. Public Health Agency of Canada. Recommendations on the use of COVID-19 vaccines [Internet]. 2020 [cited 2021 Mar 14]. Available from: https://www.canada.ca/en/publichealth/services/immunization/national-advisory-committee-on-immunizationnaci/recommendations-use-covid-19-vaccines.html

15. Government of Canada SC. Population estimates on July 1st, by age and sex [Internet]. 2017 [cited 2020 Aug 18]. Available from:

https://www150.statcan.gc.ca/t1/tbl1/en/tv.action?pid=1710000501

16. Government Of Canada SC. Proportion of adults (age 18 years and older) with at least one underlying health condition, by age group and sex [Internet]. 2020 [cited 2020 Aug 18]. Available from: https://www150.statcan.gc.ca/n1/daily-quotidien/200703/cg-a001-eng.htm

17. Public Health Ontario. COVID-19 and Severe Outcomes in Ontario [Internet]. 2020 [cited 2020 Aug 18]. Available from: https://www.publichealthontario.ca/-

/media/documents/ncov/epi/covid-19-severe-outcomes-ontario-epi-summary.pdf?la=en

18. Mossong J, Hens N, Jit M, Beutels P, Auranen K, Mikolajczyk R, et al. Social Contacts and Mixing Patterns Relevant to the Spread of Infectious Diseases. Riley S, editor. PLoS Med [Internet]. 2008 Mar 25 [cited 2020 May 22];5(3):e74. Available from: https://dx.plos.org/10.1371/journal.pmed.0050074

19. CMMID COVID-19 working group, Jarvis CI, Van Zandvoort K, Gimma A, Prem K, Klepac $P$, et al. Quantifying the impact of physical distance measures on the transmission of COVID-19 in the UK. BMC Med [Internet]. 2020 Dec [cited 2021 Jan 20];18(1):124. Available from: https://bmcmedicine.biomedcentral.com/articles/10.1186/s12916-02001597-8

20. Li Q, Guan X, Wu P, Wang X, Zhou L, Tong Y, et al. Early Transmission Dynamics in Wuhan, China, of Novel Coronavirus-Infected Pneumonia. N Engl J Med [Internet]. 2020 Mar 26 [cited 2020 Oct 27];382(13):1199-207. Available from: http://www.nejm.org/doi/10.1056/NEJMoa2001316 
medRxiv preprint doi: https://doi.org/10.1101/2020.12.10.20246827; this version posted March 18, 2021. The copyright holder for this preprint (which was not certified by peer review) is the author/funder, who has granted medRxiv a license to display the preprint in perpetuity. It is made available under a CC-BY-NC-ND 4.0 International license .

21. He X, Lau EHY, Wu P, Deng X, Wang J, Hao X, et al. Temporal dynamics in viral shedding and transmissibility of COVID-19. Nat Med [Internet]. 2020 May [cited 2020 Jun 10];26(5):672-5. Available from: http://www.nature.com/articles/s41591-020-0869-5

22. Li R, Pei S, Chen B, Song Y, Zhang T, Yang W, et al. Substantial undocumented infection facilitates the rapid dissemination of novel coronavirus (SARS-CoV-2). Science [Internet]. 2020 May 1 [cited 2020 Jun 10];368(6490):489-93. Available from: https://science.sciencemag.org/content/368/6490/489

23. Gatto M, Bertuzzo E, Mari L, Miccoli S, Carraro L, Casagrandi R, et al. Spread and dynamics of the COVID-19 epidemic in Italy: Effects of emergency containment measures. Proc Natl Acad Sci [Internet]. 2020 May 12 [cited 2020 Jun 10];117(19):10484-91. Available from: http://www.pnas.org/lookup/doi/10.1073/pnas.2004978117

24. Ferretti L, Wymant C, Kendall M, Zhao L, Nurtay A, Abeler-Dörner L, et al. Quantifying SARS-CoV-2 transmission suggests epidemic control with digital contact tracing. Science [Internet]. 2020 Mar 31 [cited 2020 Apr 16];eabb6936. Available from: https://www.sciencemag.org/lookup/doi/10.1126/science.abb6936

25. Moghadas SM, Fitzpatrick MC, Sah P, Pandey A, Shoukat A, Singer BH, et al. The implications of silent transmission for the control of COVID-19 outbreaks. Proc Natl Acad Sci [Internet]. 2020 Jul 6 [cited 2020 Jul 9]; Available from: https://www.pnas.org/content/early/2020/07/02/2008373117

26. Sayampanathan AA, Heng CS, Pin PH, Pang J, Leong TY, Lee VJ. Infectivity of asymptomatic versus symptomatic COVID-19. The Lancet [Internet]. 2020 Dec [cited 2021 Jan 3]; Available from: https://linkinghub.elsevier.com/retrieve/pii/S0140673620326519

27. Moghadas SM, Shoukat A, Fitzpatrick MC, Wells CR, Sah P, Pandey A, et al. Projecting hospital utilization during the COVID-19 outbreaks in the United States. Proc Natl Acad Sci [Internet]. 2020 Apr 21 [cited 2020 Jun 10];117(16):9122-6. Available from: https://www.pnas.org/content/117/16/9122

28. Yang $X, Y u$ Y, Xu J, Shu H, Xia J, Liu H, et al. Clinical course and outcomes of critically ill patients with SARS-CoV-2 pneumonia in Wuhan, China: a single-centered, retrospective, observational study. Lancet Respir Med [Internet]. 2020 May 1 [cited 2020 Jun 10];8(5):475-81. Available from:

https://www.thelancet.com/journals/lanres/article/PIIS2213-2600(20)30079-5/abstract

29. Sanche S, Lin YT, Xu C, Romero-Severson E, Hengartner N, Ke R. The Novel Coronavirus, 2019-nCoV, is Highly Contagious and More Infectious Than Initially Estimated. medRxiv [Internet]. 2020 Feb 11 [cited 2020 Jun 10];2020.02.07.20021154. Available from: https://www.medrxiv.org/content/10.1101/2020.02.07.20021154v1

30. Polack FP, Thomas SJ, Kitchin N, Absalon J, Gurtman A, Lockhart S, et al. Safety and Efficacy of the BNT162b2 mRNA Covid-19 Vaccine. N Engl J Med [Internet]. 2020 Dec 31 [cited 2021 Jan 17];383(27):2603-15. Available from: http://www.nejm.org/doi/10.1056/NEJMoa2034577

31. Baden LR, El Sahly HM, Essink B, Kotloff K, Frey S, Novak R, et al. Efficacy and Safety of the mRNA-1273 SARS-CoV-2 Vaccine. N Engl J Med [Internet]. 2020 Dec 30 [cited 2021 Jan 17];NEJMoa2035389. Available from: http://www.nejm.org/doi/10.1056/NEJMoa2035389

32. Dagan N, Barda N, Kepten E, Miron O, Perchik S, Katz MA, et al. BNT162b2 mRNA Covid-19 Vaccine in a Nationwide Mass Vaccination Setting. N Engl J Med [Internet]. 2021 Feb 24 [cited 2021 Mar 14];NEJMoa2101765. Available from: http://www.nejm.org/doi/10.1056/NEJMoa2101765

33. U.S. Food and Drug Administration. Pfizer-BioNTech COVID-19 Vaccine VRBPAC Briefing Document. 2020 Dec; Available from: https://www.fda.gov/media/144246/download

34. U.S. Food and Drug Administration. Moderna COVID-19 Vaccine VRBPAC Briefing Document [Internet]. 2020 Dec [cited 2021 Mar 14]. Available from: 
medRxiv preprint doi: https://doi.org/10.1101/2020.12.10.20246827; this version posted March 18, 2021. The copyright holder for this preprint (which was not certified by peer review) is the author/funder, who has granted medRxiv a license to display the preprint in perpetuity.

It is made available under a CC-BY-NC-ND 4.0 International license .

https://www.fda.gov/media/144434/download

35. Lipsitch $\mathrm{M}$, Kahn $\mathrm{R}$. Interpreting vaccine efficacy trial results for infection and transmission [Internet]. medRxiv; 2021 Feb [cited 2021 Mar 14]. Available from:

http://medrxiv.org/lookup/doi/10.1101/2021.02.25.21252415

36. SeroTracker. SeroTracker [Internet]. [cited 2021 Feb 24]. Available from: https://serotracker.com/en/Explore

37. Rt Canada [Internet]. Rt Canada. [cited 2021 Mar 15]. Available from: https://rt-canada.ca

38. Mizumoto K, Kagaya K, Zarebski A, Chowell G. Estimating the asymptomatic proportion of coronavirus disease 2019 (COVID-19) cases on board the Diamond Princess cruise ship, Yokohama, Japan, 2020. Eurosurveillance [Internet]. 2020 Mar 12 [cited 2020 Jun 19];25(10). Available from: https://www.ncbi.nlm.nih.gov/pmc/articles/PMC7078829/

39. Nishiura H, Kobayashi T, Miyama T, Suzuki A, Jung S-M, Hayashi K, et al. Estimation of the asymptomatic ratio of novel coronavirus infections (COVID-19). Int J Infect Dis IJID Off Publ Int Soc Infect Dis. 2020;94:154-5.

40. Buitrago-Garcia D, Egli-Gany D, Counotte MJ, Hossmann S, Imeri H, Ipekci AM, et al. Occurrence and transmission potential of asymptomatic and presymptomatic SARS-CoV-2 infections: A living systematic review and meta-analysis. PLOS Med [Internet]. 2020 Sep 22 [cited 2020 Dec 9];17(9):e1003346. Available from:

https://journals.plos.org/plosmedicine/article?id=10.1371/journal.pmed.1003346

41. Davies NG, Abbott S, Barnard RC, Jarvis CI, Kucharski AJ, Munday JD, et al. Estimated transmissibility and impact of SARS-CoV-2 lineage B.1.1.7 in England. Science [Internet]. 2021 Mar 3 [cited 2021 Mar 14];eabg3055. Available from:

https://www.sciencemag.org/lookup/doi/10.1126/science.abg3055

42. Volz E, Mishra S, Chand M, Barrett JC, Johnson R, Geidelberg L, et al. Transmission of SARS-CoV-2 Lineage B.1.1.7 in England: Insights from linking epidemiological and genetic data. medRxiv [Internet]. 2021 Jan 4 [cited 2021 Feb 19]; Available from: https://www.medrxiv.org/content/10.1101/2020.12.30.20249034v2

43. lacobucci G. Covid-19: New UK variant may be linked to increased death rate, early data indicate. BMJ [Internet]. 2021 Jan 26 [cited 2021 Mar 14];n230. Available from: https://www.bmj.com/lookup/doi/10.1136/bmj.n230

44. Davies NG, Jarvis CI, CMMID COVID-19 Working Group, Edmunds WJ, Jewell NP, DiazOrdaz K, et al. Increased mortality in community-tested cases of SARS-CoV-2 lineage B.1.1.7 [Internet]. medRxiv; 2021 Feb [cited 2021 Mar 14]. Available from: http://medrxiv.org/lookup/doi/10.1101/2021.02.01.21250959

45. Brown KA, Gubbay J, Hopkins J, Patel S, Buchan SA, Daneman N, et al. Rapid Rise of SGene Target Failure and the UK variant B.1.1.7 among COVID-19 isolates in the Greater Toronto Area, Canada [Internet]. medRxiv; 2021 Feb [cited 2021 Mar 14]. Available from: http://medrxiv.org/lookup/doi/10.1101/2021.02.09.21251225

46. Public Health Ontario. COVID-19 in Ontario: January 15, 2020 to March 13, 2021 [Internet]. 2020. Available from: https://www. publichealthontario.ca//media/documents/ncov/epi/covid-19-daily-epi-summary-report.pdf

47. Voysey M, Costa Clemens SA, Madhi SA, Weckx LY, Folegatti PM, Aley PK, et al. Singledose administration and the influence of the timing of the booster dose on immunogenicity and efficacy of ChAdOx1 nCoV-19 (AZD1222) vaccine: a pooled analysis of four randomised trials. The Lancet [Internet]. 2021 Mar [cited 2021 Mar 14];397(10277):88191. Available from: https://linkinghub.elsevier.com/retrieve/pii/S0140673621004323

48. Moghadas SM, Vilches TN, Zhang K, Nourbakhsh S, Sah P, Fitzpatrick MC, et al. Evaluation of COVID-19 vaccination strategies with a delayed second dose [Internet]. medRxiv; 2021 Jan [cited 2021 Mar 14]. Available from: http://medrxiv.org/lookup/doi/10.1101/2021.01.27.21250619

49. lacobucci $\mathrm{G}$, Mahase $\mathrm{E}$. Covid-19 vaccination: What's the evidence for extending the 
medRxiv preprint doi: https://doi.org/10.1101/2020.12.10.20246827; this version posted March 18, 2021. The copyright holder for this preprint (which was not certified by peer review) is the author/funder, who has granted medRxiv a license to display the preprint in perpetuity. It is made available under a CC-BY-NC-ND 4.0 International license .

dosing interval? BMJ [Internet]. 2021 Jan 6 [cited 2021 Mar 14];n18. Available from: https://www.bmj.com/lookup/doi/10.1136/bmj.n18

50. Lazarus JV, Ratzan SC, Palayew A, Gostin LO, Larson HJ, Rabin K, et al. A global survey of potential acceptance of a COVID-19 vaccine. Nat Med [Internet]. 2021 Feb [cited 2021 Mar 14];27(2):354-354. Available from: http://www.nature.com/articles/s41591-020-012260 
medRxiv preprint doi: https://doi.org/10.1101/2020.12.10.20246827; this version posted March 18, 2021. The copyright holder for this preprint (which was not certified by peer review) is the author/funder, who has granted medRxiv a license to display the preprint in perpetuity.

It is made available under a CC-BY-NC-ND 4.0 International license .

Table 1. Description of model parameters and their estimates.

\begin{tabular}{|c|c|c|c|c|c|c|}
\hline Description & $0-4$ & $5-19$ & 20-49 & $50-64$ & $\geq 65$ & Source \\
\hline $\begin{array}{l}\text { Transmission probability per } \\
\text { contact during pre- } \\
\text { symptomatic stage }\end{array}$ & \multicolumn{5}{|c|}{0.1524} & $\begin{array}{l}\text { Calibrated to } \\
\qquad \begin{array}{c}R_{e}=1.12 \\
(37)\end{array}\end{array}$ \\
\hline Incubation period (days) & \multicolumn{5}{|c|}{ LogNormal(shape: 1.434 , scale: 0.661 ) } & (20) \\
\hline Asymptomatic period (days) & \multicolumn{5}{|c|}{ Gamma(shape: 5 , scale: 1 ) } & Derived from $(22,23)$ \\
\hline Pre-symptomatic period (days) & \multicolumn{5}{|c|}{ Gamma(shape: 1.058 , scale: 2.174$)$} & Derived from (21) \\
\hline $\begin{array}{l}\text { Infectious period after the } \\
\text { onset of symptoms (days) }\end{array}$ & \multicolumn{5}{|c|}{ Gamma(shape: 2.768, scale: 1.1563$)$} & Derived from (22) \\
\hline $\begin{array}{l}\text { Proportion of infections that } \\
\text { are asymptomatic }\end{array}$ & 0.30 & 0.38 & 0.33 & 0.33 & 0.19 & $(38-40)$ \\
\hline $\begin{array}{l}\text { Proportion of symptomatic } \\
\text { cases that exhibit mild } \\
\text { symptoms }\end{array}$ & 0.95 & 0.9 & 0.85 & 0.60 & 0.20 & $(12,27)$ \\
\hline $\begin{array}{l}\text { Proportion of cases } \\
\text { hospitalized with one or more } \\
\text { comorbid condition }\end{array}$ & \multicolumn{5}{|c|}{$23.5 \%$} & \multirow{3}{*}{$(17)$} \\
\hline Non-ICU & \multicolumn{5}{|c|}{$73.9 \%$} & \\
\hline ICU & \multicolumn{5}{|c|}{$26.1 \%$} & \\
\hline $\begin{array}{l}\text { Proportion of cases } \\
\text { hospitalized without any } \\
\text { comorbid condition }\end{array}$ & \multicolumn{5}{|c|}{$8.9 \%$} & \multirow{3}{*}{$(17)$} \\
\hline Non-ICU & \multicolumn{5}{|c|}{$80.3 \%$} & \\
\hline ICU & \multicolumn{5}{|c|}{$19.7 \%$} & \\
\hline Length of non-ICU stay & \multicolumn{5}{|c|}{ Gamma(shape: 4.5 , scale: 2.75$)$} & $\begin{array}{l}\text { Derived from } \\
\quad(28,29)\end{array}$ \\
\hline Length of ICU stay & \multicolumn{5}{|c|}{ Gamma(shape: 4.5 , scale: 2.75$)+2$} & $\begin{array}{l}\text { Derived from } \\
(28,29)\end{array}$ \\
\hline
\end{tabular}


medRxiv preprint doi: https://doi.org/10.1101/2020.12.10.20246827; this version posted March 18, 2021. The copyright holder for this preprint (which was not certified by peer review) is the author/funder, who has granted medRxiv a license to display the preprint in perpetuity.

It is made available under a CC-BY-NC-ND 4.0 International license.

\section{Figures}
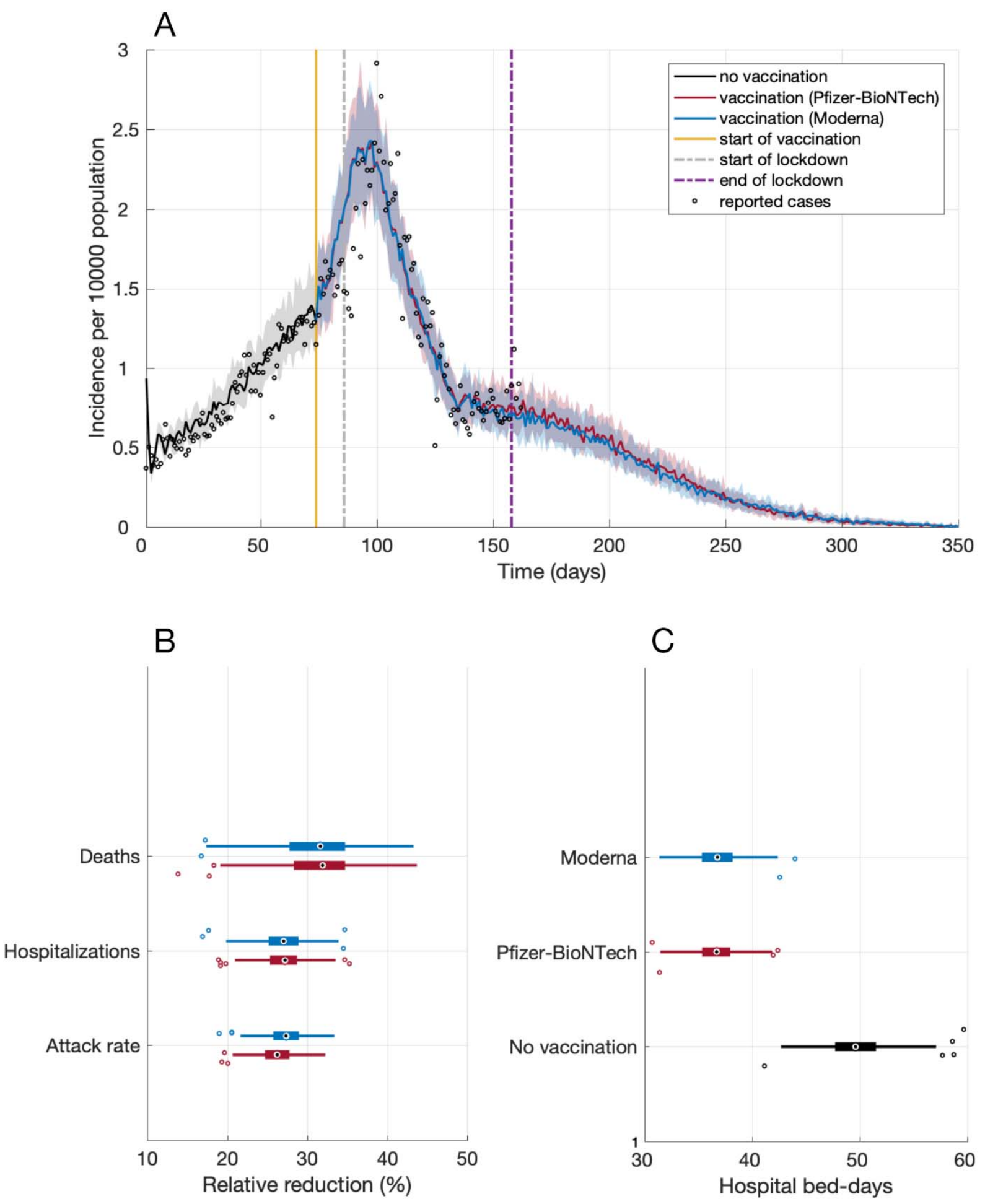

Figure 1. (A) Projected incidence of infection with fitting to reported cases per 10,000 population from October 1, 2020 (day 0) to March 12, 2021 (day 162). (B) Projected reduction of 
medRxiv preprint doi: https://doi.org/10.1101/2020.12.10.20246827; this version posted March 18, 2021. The copyright holder for this preprint (which was not certified by peer review) is the author/funder, who has granted medRxiv a license to display the preprint in perpetuity.

It is made available under a CC-BY-NC-ND 4.0 International license .

overall attack rate, hospitalizations and deaths from the start of vaccination (day 74) compared to no vaccination for a time horizon of one year. (C) Projected number of hospital bed-days per 10,000 population from day 74 for one year. Box plots indicate interquartile range (IQR), and horizontal lines are the extended range from minimum (25th percentile - 1.5 IQR) to maximum (75th percentile + 1.5 IQR).
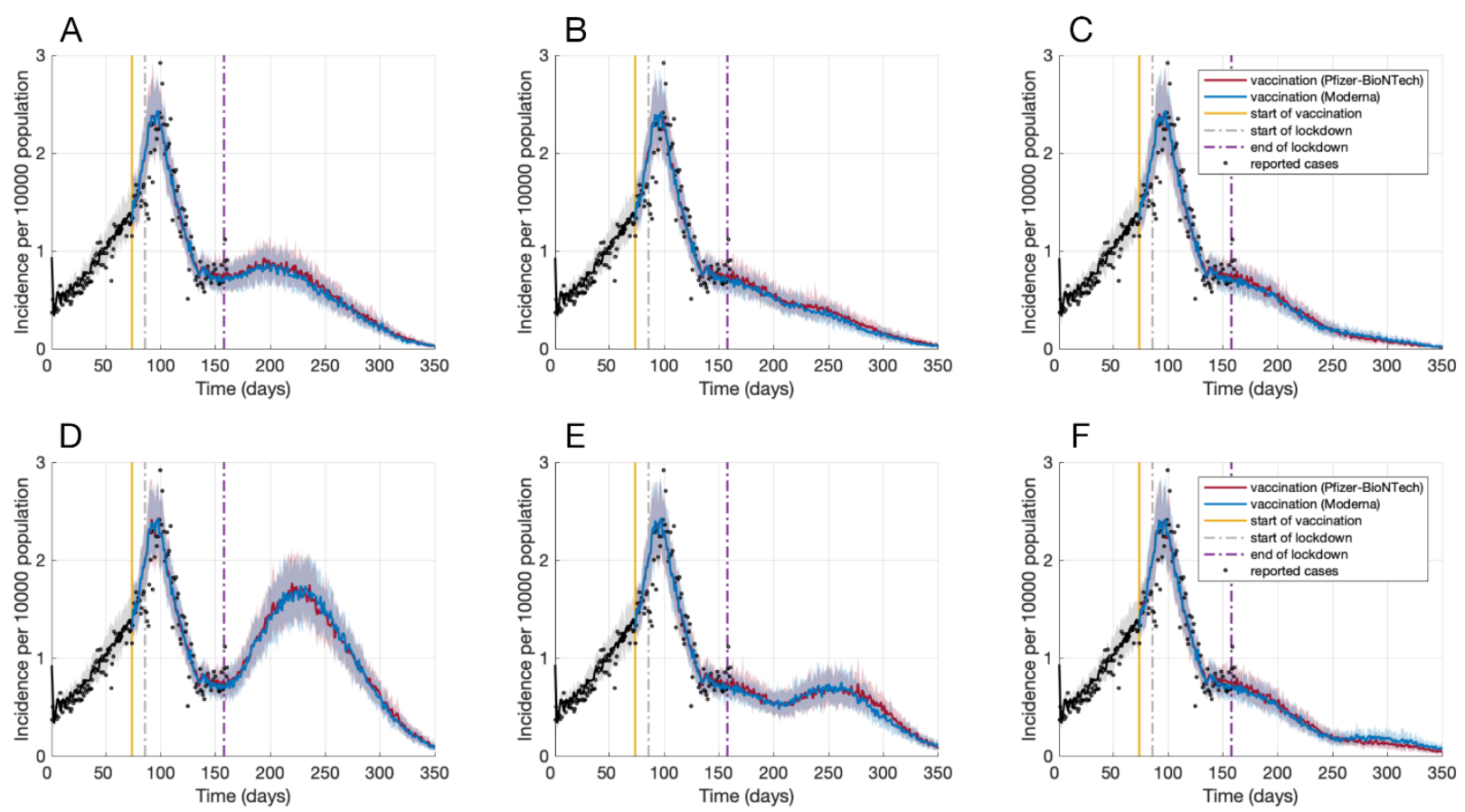

Figure 2. Projected incidence of infection per 10,000 population post-lockdown with a $10 \%$ increase in the daily number of contacts on day 158 (A), 200 (B), or 250 (C), and with a $20 \%$ increase in the daily number of contacts on day 158 (D), $200(E)$, or $250(F)$. 